\section{Janusz Kręcidło MS}

Cardinal Stefan Wyszyński University, Warsaw

j.krecidlo@wp.pl

DOI: http://dx.doi.org/10.12775/BPTh.2017.017
Biblica

et

Patristica

Thoruniensia

10 (2017) 3: 323-339

ISSN (print) 1689-5150

ISSN (online) 2450-7059

\title{
Aquinas' Exegetical Mastery in Super Evangelium S. Joannis Lectura. A Case Study of John 21
}

\author{
Mistrzostwo egzegetyczne Akwinaty \\ w Super Evangelium S. Joannis Lectura. \\ Analiza J 21
}

\begin{abstract}
The article has four scopes. Firstly, it aims at exposing focal principles of Aquinas' exegesis. This will be shown against a background of medieval scholastic exegesis. Secondly, Thomas Aquinas' commentary on the Gospel of John will be shortly presented. Thirdly, it will be shown, while analyzing the case study of chapter 21 of the Gospel of John (just a few samples), how Thomas Aquinas applies his exegetical principles in order to unfold the meaning of a biblical text. While doing that, the results of Thomas' exegesis on John 21 will be consulted with the contemporary exegetical status quesionis.
\end{abstract}

Streszczenie. Artykuł posiada cztery cele. Po pierwsze, przedstawia zasady egzegezy Akwinaty na tle średniowiecznej, scholastycznej egzegezy. Po drugie, prezentuje komentarz Tomasza z Akwinu do Ewangelii wg św. Jana, a następnie analizując rozdział 21 tejże Ewangelii (kilka przykładów), pokazuje jak Tomasz stosuje swoje egzegetyczne zasady w rozwijaniu znaczenia tekstu biblijnego. W ostatnim kroku, rezultaty Tomaszowej egzegezy J 21 zostaną porównane ze współczesnym, egzegetycznym status quaestionis.

Keywords: Thomas Aquinas; Super Evangelium S. Joannis Lectura; medieval exegesis; exegetical methods; John 21.

Słowa kluczowe: Tomasz z Akwinu; Super Evangelium S. Joannis Lectura; egzegeza średniowieczna; metody egzegetyczne; J 21. 


\section{Preliminary remarks}

Teryone who has done even a cursory search query on contemporary scholCarly works concerning Aquinas' biblical commentaries has to agree that they are, in many respects, a neglected part in the field of studies of the Angelic Doctor's contributions ${ }^{1}$ for he is studied nowadays primarily for his philosophical contributions. When it comes to his theological achievements, it is the Summa Theologiae and Summa Contra Gentiles that are explored. But it has to be noted that Aquinas never taught philosophy or systematic theology in his entire career! Instead, in Naples, Rome and Paris, he was recognized as a magister in sacra pagina - "master of the sacred page," namely, he gave lectures commenting on the Sacred Scriptures. Therefore, as a teacher he was a committed Bible scholar, even though he has never written a single biblical commentary.

\section{Focal principles of Aquinas' exegesis against a background of medieval scholastic exegesis}

In order to be able to understand the mastery of Aquinas' exegetical strategy it seems to be necessary to place it within the framework of medieval biblical hermeneutics. Even not long ago there was a conviction among historians and ordinary people that the Middle Ages were the period of stagnation and even more - backwardness in the progress of Western civilization. The bad fame of that period was so strong that the expression "Dark Ages" is still in English an equivalent of "the Middle Ages." Nowadays, more and more courageously, the period of the Middle Ages is being rehabilitated by demonstrating the richness and variety of its thought. The same is true regarding the estimation of various benefits of the medieval scholars in interpretation of the Bible.

It is not possible to simply synthetize all exegetical achievements from the $6^{\text {th }}$ till $15^{\text {th }}$ century, because it is too complex. ${ }^{2}$ It seems to be necessary to distinguish at least two periods: continuation and deepening of patristic exegesis, and birth and development of scholasticism (from $12^{\text {th }}$ century on).

1 The same observation is given by Thomas G. Weinandy, Daniel A. Keating, John A. Yocum in their introduction to the volume: Aquinas on Scripture: An Introduction to his biblical Commentaries, T \& T Clark International, London, 2004, p. IX.

2 Issues developed in this part of the article are broadly treated in: J. Kręcidło, Hermeneutyka biblijna, in: Wstęp ogólny do Biblii, P. Walewski (ed.), Series Religiologica Pomeraniae 2, Rumia 2011, pp. 291-294. 
The medieval interpreters of the Bible considered themselves to be the inheritors of the patristic exegesis. It is well-depicted by a Latin hexameter that was coined at that time. It skillfully describes achievements of all patristic exegetical schools: Littera gesta docet, quid credas allegoria, moralis quid agas, quo tendas anagogia - "The letter speaks of deeds, allegory to faith, the moral how to act, anagogy our destiny." It is sufficient to recall hermeneutical rules of biblical exegesis formulated by Augustine of Hippo (354-430) mostly in his two prominent works: De doctrina christiana and De civitate Dei. They are extremely important, because Augustinian synthesis was the foundation of Christian exegesis in at least the succeeding thousand years. ${ }^{3}$ Augustine argues that in order to comprehend a proper sense of any biblical passage the question of meaning that the biblical author wanted to assign to it is crucial. ${ }^{4}$ The meaning assigned by an author is for Augustine equal to literal sense which is foundational for all other senses. Apart from the literal sense, Augustine indicates three other: aetiological that specifies the origins or causes of things, analogical, and allegorical. ${ }^{5}$ This Augustinian concept was the touchstone for the Western patristic theory of fourfold biblical sense (namely literal, allegorical, tropological [moral], and anagogical [mystical, eschatological]) that was the basis for medieval biblical exegesis.

It is necessary to mention here a few words about the premises of Western patristic exegesis that were defused by Augustine and then taken for granted by the Middle Ages. He argued that the Bible is the Sacred Scripture, inspired by God. It is infallible and it has the highest authority in matters of faith. His second main presumption was that outside the Church there is no salvation, its authority yields only to the authority of the Bible. Therefore, biblical interpretation should be performed according to the regula fidei (rule of faith) that is rooted in the conviction that only the Church under the inspiration of the Holy Spirit is authorized and able to unveil the truth present/hidden in the Bible. Hence, every individual interpretation that results from a speculative mind, and is not rooted in the authority of tradition that represents the regula fidei and is present in creeds, apostolic teaching, writings of the Church Fathers

3 See more in: J. T. Spivey Jr., The Hermeneutics of the Medieval and Reformation Era, in: Biblical Hermeneutics: A Comprehensive Introduction to Interpreting Scripture, B. Corley, S. W. Lemke, G. I. Lovejoy (eds.), Nashville 2002, pp. 101-103.

4 De doctrina christiana 1.41.

5 See: W. C. Kaiser, M. Silva, An Introduction to Biblical Hermeneutics: The Search for Meaning, Zondervan Publishing House, Grand Rapids 1994, p. 222; J. T. Spivey Jr., The Hermeneutics of the Medieval and Reformation Era, in: Biblical Hermeneutics, pp. 102-103. 
and decisions of Church councils leads to a heresy. ${ }^{6}$ His hermeneutical scheme adopted later by medieval exegesis is based on three principles: "come to the Bible in faith, stay within the regula fidei, and apply the law of love." But one would be absolutely wrong stating that these principles suffocated freedom and objective value of exegetical explanation of biblical passages. In De doctrina christiana Augustine gives very precise interpretive rules: "to know and use the original languages, remember that words do not mean the same thing in all contexts, explain obscure passages by clear once, understand numerology, apply secure knowledge and experience when appropriate, and determine the literal and the figurative senses."

As stated above, exegetes in the Middle Ages considered themselves the inheritors of patristic biblical interpretation, therefore largely accepted and applied the hermeneutical rules of the Fathers of the Church. The principle of the authority of the tradition of the Church determined the basic exegetical model used by all medieval exegetes. The essential stage of medieval biblical interpretation was to comment the scriptural passages by quotations taken from commentaries of the Church Fathers on them (the so-called catenae - chains). The favourite ones were commentaries of Augustine and Jerome. Quotations taken from the Fathers were to prove consistency of given interpretation with tradition and prevailing teaching of the Church.

Biblical studies in the Middle Ages were orientated towards deepening of believers' spiritual life. They were practiced in two ambiences: monastic schools and cathedral schools. The monastic schools referenced mainly to Alexandrian allegorical exegesis and practiced the so-called devotio lectio. It was an elitist exegesis based on the conviction that exposing of the true sense of the scriptural passages was a privilege of distinguished and appropriately prepared scholars. The second type of medieval exegetical schools was founded by Alcuin (735-804) the abbot of Tours, and royal tutor. It came into being in the Carolingian system of education in the cathedral schools. Alcuin renewed the use of the liberal arts and revised the Vulgate, but his followers introduced dialectics, logic and grammar studies into interpretation of scriptural passages.

A very important contribution was given by archbishop of Canterbury Lanfranc (1010-1089) who was a founder of cathedral schools in England. ${ }^{9}$ In

6 J. T. Spivey Jr., The Hermeneutics of the Medieval and Reformation Era, in: Biblical Hermeneutics, p. 102.

7 Ibid.

8 Ibid.

9 He founded the first school in Bec in Normandy in the northern France and then he moved it to Canterbury. 
his school he encouraged students to comment on biblical text while hearing lectures given by masters. They were to insert marginal or interlinear notes/ glosses based on the regula fidei and editorial theology. Successive generations of students added their own glosses and thus the students' notes developed into the so-called glossa ordinaria and became biblical commentaries. It was the new standard of biblical interpretation that was commonly used by medieval interpreters, including Thomas Aquinas.

One more medieval predecessor of Aquinas in biblical theological studies must be mentioned here - Peter Abelard (1079-1142) who is considered to be a founder of medieval scholastic method. In his work Sic et Non Abelard challenged traditional doctrine of the Church in a dialectical and skeptical fashion. In biblical interpretation he focused on comprehension of literal sense of a commented text. He argued also that in the literal sense other figurative senses can be present, including allegorical. As an enthusiast of Aristotle, Abelard argued that precise logic is a better tool in interpreting biblical texts than faith. In his theological works he gave priority to logic, dialectic and rhetoric over arguments based on interpretation of the Bible in the Church tradition.

Thomas Aquinas was a man of his time. On the basis of what was written above I will briefly develop his characterization as commentator of the Bible putting aside his philosophical and theological contributions. ${ }^{10}$ In biblical interpretation he was faithful to the rules of patristic exegesis inherited in the Church tradition and transmitted to him by his scholarly master Albert the Great (ca. 1205-1280). He held that the Holy Spirit is the author of the Bible. ${ }^{11}$ He also argued that the literal sense is the basis of all other senses and includes everything that is necessary to believe. ${ }^{12}$ But he stated that true spiritual sense of biblical passages can be derived from the literal sense only by means of deduction and it has to be consistent with author's intent. Moral sense coincides, in his opinion, with the literal one. Aquinas accepted allegorical sense as well, arguing that it should be derived from the literal sense and he appreciated the value of allegorical sense for a devotional/spiritual reading of the Bible. ${ }^{13}$ Stud-

10 An attempt to give a sketch of Aquinas's exegetical method is given in the first part of the doctoral dissertation: Ch. T. Baglow, "Modus et Forma": A New Approach to the Exegesis of Saint Thomas Aquinas with an Application to the Lectura super Epistolam ad Ephesios, Analecta Biblica 149, Rome 2002. Unfortunately some focal points are missing here.

11 See: A. C. Thiselton, Hermeneutics: An Introduction, Grand Rapids 2009, p.121.

12 W. W. Klein, C. L. Blomberg, R. L. Hubbard, Introduction to Biblical Interpretation, Nashville 1993, p. 39.

13 J. T. Spivey Jr., The Hermeneutics of the Medieval and Reformation Era, p. 108. 
ies of Thomas' commentaries prove that he was "deeply and profoundly a biblical theologian." ${ }^{14}$

\section{Short presentation of Aquinas' commentary on the Gospel of John}

Between 1270 and 1272 Aquinas delivered lectures on the Gospel of John at the University of Paris. He ended teaching in Paris two years before his death being at the peak of his scholarly powers, therefore Super Joannem is considered to be "among the most fully finished and most profound" 15 of all his scriptural commentaries. As I have already mentioned, unlike his other philosophical and theological works, Aquinas did not write a single biblical commentary. Being a man of his time, he commented on biblical books during his lectures, while his students diligently wrote course notes, the so-called reportatio. The same was true regarding his commentary on John as it is proved by his faithful student and scribe in the original manuscript of Lectura super Joannem:

"Here therefore is what I, Friar Reginald of Piperno, of the Order of Preachers, at the request of certain companions and particularly at the order of the reverend Father Lord Provost of Saint-Omer, have gathered together in following friar Thomas Aquinas - just like - just like he who gathers the grapes [left] after the harvest. Please God that it is not too inadequate to the work." 16

Aquinas probably never revised Reginald's reportatio, but its quality had to be really high, given that it was accepted by the University of Paris as an official copy. ${ }^{17}$

Before presenting a sample from John 21 that will demonstrate Aquinas's exegetical mastery it seems necessary to demonstrate his main premises. First of all, as heir of patristic tradition, Aquinas believed that Scripture was authored by God, i.e., written by men inspired by the Holy Spirit. Exegetical scholarly activity should not aim, above all, at acquiring new information but at attaining sapiential contemplation of God, named the sacra doctrina. The purpose of bib-

14 T. G. Weinandy, D. A. Keating, J. A., Aquinas on Scripture: An Introduction to his biblical Commentaries, p. IX.

15 See: J.-P. Torrell, Saint Thomas Aquinas, vol. 1, The Person and His Work, trans. R. Royal, Washington, D.C., 1996, p. 200.

16 Quoted by: Ibid., p. 198-199.

17 See: St. Thomas Aquinas, Commentary on the Gospel of John, vol. 1, Chapters 1-5, transl. F. Larcher, J. A. Weisheipl, Washington, D.C., 2010, p. IX. 
lical studies was meant to be a participation in the knowledge of God, having a foretaste of beatific contemplation.

Aquinas did not make a strict separation between his commentaries on biblical books and other theological works. ${ }^{18}$ The same discussions of sacra doctrina that are present in Lectura super Joannem we can find in the Summa Theologiae as well. ${ }^{19}$ The difference is that he commented on the text of the Gospel verse after verse, as lectio continua, whereas in the Summa Theologiae he focused on explaining a given topic. The vehicle to perform theological inquiry of biblical texts was "reason and dialectic" (especially Aristotle, his philosophy, rhetoric and politics). ${ }^{20}$

As to his exegetical procedure in commenting on the Gospel of John, his first step is always to determine basic literal sense, mostly by describing historical and literary context of commented pericope. Then he goes phrase after phrase, illuminating them comprehensively by exposition of literal and spiritual sense, without dividing it into moral, analogical and allegorical, but simply when it is proper calling it "mystical."

Apart from reason and dialectic, the sense of a passage or short phrase is brought out by explaining it in the light of parallel biblical passages. This operation of interpreting Scripture through Scripture is very important in Aquinas's exegesis. He also gives many associations from the Old and the New Testament to the commented phrase. The profusion of parallel biblical passages that he gives is really impressive. In the present-day biblical scholarship this exegetical procedure has been undertaken and developed by Brevard Childs in his canonical approach. As Childs rightly states, the way Aquinas illuminates biblical passages through others can be perceived as a very sophisticated form of intertextuality ${ }^{21}$ that, in my opinion, is inaccurately thought to be by many contemporaries an invention of modern literary academics like Julia Kristeva and Gérard Genette. ${ }^{22}$

18 See: T. Prügl, Thomas Aquinas as Interpreter of Scripture, in: The Theology of Thomas Aquinas, ed. R. Van Nieuwenhove, J. Wawrykow, University of Notre Dame Press 2005, p. 403.

19 At the time when he was lecturing on the Gospel of John in Paris, he also commented the works of Aristotle and wrote the third part of the Summa Theologiae.

20 See: N. M. Healy, Introduction, in: Aquinas on Scripture: An Introduction to His Biblical Commentaries, ed. T. G. Weinandy, D. A. Keating, J. P. Yocum, New York 2005, p. 12.

21 See: B. Childs, The Struggle to Understand Isaiah as Christian Scripture, Grand Rapids 2004, p. 160.

22 J. Kristeva, Semiotikè: recherches pour une sémanalyse, Paris 1969; G. Genette, Palimpsestes: La literature au second degré, Editions Seuil 1982. See also my article: Intertextuality and Sacra Scriptura, The Biblical Annales (in the course of publication). 
Another essential exegetical technique applied by the Angelic Doctor in the Lectura super Joannem in order to illuminate spiritual sense of a passage is an ample citation of the Church Fathers. As I have mentioned above, it was typical for exegesis in the Middle Ages. In Thomas's time there were few collected catenae of patristic citations from which he could quote. But it has to be reminded as well that in the 1260s pope Urban VI, entrusted him a task of providing a Gospel commentary based on the Latin and Greek Fathers. By the time Aquinas was lecturing in Paris in the early 1270s he had already completed immense four-volume commentary to each of the canonical Gospels, the so-called Catena aurea (The Golden Chain). In the commentary, Thomas cites more than fifty authors both from patristic and medieval period (Glossa Ordinaria and Glossa Interlinearis). Interestingly enough, in the Catena aurea to the Gospel of John Aquinas cites far fewer authors (only sixteen) than in the volumes dedicated to the synoptics. His favorites ones are three: Origen, Augustine and John Chrysostom. ${ }^{23}$

\section{Aquinas' application of exegetical principles to John 21 vs. contemporary exegetical status questionis on it}

The first thing that could seem strange to a contemporary, 21st century Biblical scholar while opening the commentary is that the author did not give any introduction to it, in order to explain crucial historic-critical issues (date of writing, authorship etc.), outline inner structure of the Gospel of John and assign titles and subtitles to larger and smaller literary units. Given that he was commenting the Latin Vulgate text of the FG, it is hardly imaginable to contemporary lecturer that he would not have said a word of introduction to the whole book. We can assume that since it is a reportatio of Reginald of Piperno that was strictly connected with a commented text, an introduction could have been provided by Thomas but it was not considered to be necessary for the approved version.

Aquinas divided the chapter 21 of the Fourth Gospel in Lectura super Joannem into six units, and presumably commented on each of them during one lecture. The units are as follows: lecture 1: verses 1-6; lecture 2: verses 7-14; lecture 3: verses 15-17; lecture 4: verses 18-19a; lecture 5: verses 19b-23; lecture 6: verses 24-25. Assuming that the division of biblical books into chapters is the work of Stephen Langton, archbishop of Canterbury, from around 1227, Aquinas probably applied it in the commentary; yet the division of units within

23 See: St. Thomas Aquinas, Commentary on the Gospel of John, vol. 1, p. XIX. 
chapters can be assigned to Thomas himself. Concerning the above quoted division of chapter 21 of FG one can judge that it is done according to basic narrative criteria: change of time, location, and characters. The same standards are dominant in the contemporary exegesis.

We can assume that Thomas before having commented a unit of the FG during a lecture, had read it from the Vulgate and then explained in the words that were precisely and literary written down by the "faithful scribe" Reginald of Piperno.

On the basis of the overall assessment some observation on details from Aquinas' commentary to John 21 are given below, taking as a sample Aquinas' first lecture, namely on John 21:1-6. ${ }^{24}$

1 After this Jesus revealed himself again to the disciples by the Sea of Tiberias; and he revealed himself in this way. 2 Simon Peter, Thomas called the Twin [Didymus], Nathanael of Cana in Galilee, the son of Zebedee, and two others of his disciples were together. 3 Simon Peter said to them, "I am going fishing." They said to him, "We will go with you." They went out and got into the boat; but that night they caught nothing. 4 Just as day was breaking, Jesus stood on the beach; yet the disciples did not know that it was Jesus. 5 Jesus said to them, "Children, have you any fish?" They answered him, "No." 6 He said to them, "Cast the net on the right side of the boat, and you will find some." So they cast it, and now they were not able to haul it in, for the quantity of fish.

After citing the Latin translation of the whole unit (vv. 1-6) which is to be commented during the first lecture on J 21, Thomas explains its location in reference to the preceding context of the Gospel. He opens the explanation with the statement: "The Evangelist has just told us of two appearances of Christ to his disciples. Now he mentions the third appearance." ${ }^{25}$ It is exactly what would a contemporary biblical scholar do when commenting on it. Then Aqui-

24 postea manifestavit se iterum Iesus ad mare Tiberiadis manifestavit autem sic ${ }^{2}$ erant simul Simon Petrus et Thomas qui dicitur Didymus et Nathanahel qui erat a Cana Galilaeae et fili Zebedaei et alii ex discipulis eius duo ${ }^{3}$ dicit eis Simon Petrus vado piscari dicunt ei venimus et nos tecum et exierunt et ascenderunt in navem et illa nocte nihil prendiderunt ${ }^{4}$ mane autem iam facto stetit Iesus in litore non tamen cognoverunt discipuli quia Iesus est ${ }^{5}$ dicit ergo eis Iesus pueri numquid pulmentarium habetis responderunt ei non ${ }^{6}$ dixit eis mittite in dexteram navigii rete et invenietis miserunt ergo et iam non valebant illud trahere a multitudine piscium

25 See English translation: St. Thomas Aquinas, Commentary on the Gospel of John, vol. 3, Chapters 13-21, transl. F. Larcher, J. A. Weisheipl, Washington, D.C., 2010, p. 282 (nr. 2569). For the sake of precision, I will be referring further in the text to the numbers in Lectura super Joannem and not to the pages in the English translation. 
nas states that the Evangelist had in mind two appearances of the Risen Jesus to his disciples narrated in the $20^{\text {th }}$ chapter. What distinguishes Thomas from present-day commentators on John is that they do not go further, or if they do, they explain the motif that in fact it was not the third apparition of the Risen Lord but the fourth one, since he revealed himself to Mary Magdalene as well. Then they extend the discussion in the direction that the Evangelist could not count this latter appearance, since she was not Jesus' disciple. Unlike them, Aquinas does not even mention the problem, but comments the data in light of the sacra doctrina arguing that the first Christ's appearance showed his "divine authority by his breathing the Holy Spirit upon them; the second showed that he was the same person as before since he let them view his wounds; and the third showed the reality of his risen human nature, for he ate with them." ${ }^{26}$

Thus, Thomas gives a contextual theological framework in which the whole chapter 21 should be read. Present-day exegesis, after almost a century of being semi-paralyzed by historical-critical method that focused mainly on details illuminating the understanding of a commented text, has come to the awareness typical of patristic and medieval exegesis that it is the theological wide-ranging context of a text that determines the meaning of words and single units, not vice-versa.

Immediately after that the Angelic Doctor gives an outline of the inner structure of the whole chapter 21 . But he presents it without an unnecessary overloading with details characteristic of contemporary biblical scholarship. Modern commentators on John or other biblical texts usually make a very exhaustive vivisection of a commented passage and tend to explore as many stylistic features as they can detect. Surprisingly enough, when one opens a few contemporary commentaries on the same passage and compares detailed structures proposed by authors, it appears that usually they give slightly different proposals. Thomas remains on a very general level in structuring John 21 , simply demonstrating the progress of action: "There are two parts in this. The Evangelist first mentions Christ's dealing with a group of the disciples; secondly with two of them he especially loved (v. 15)."27

The next step in commenting on John 21 which reflects the identical procedure applied by Thomas in the whole commentary is to explain the most significant details. An overall impression one gets from reading the exegetical explanation given in the first lecture (passage 21:1-6) is that Aquinas considers biblical text as a means of expressing the sacra doctrina; this is the same aim

\footnotetext{
26 Ibid., nr. 2569.

27 Ibid., no. 2569.
} 
that motivated him to writing purely theological works like the Summa Theologiae.

He achieves the goal by using easily detectable exegetical procedure:

1) describing the literal sense of a word or phrase by the aid of reasoning from the context;

2) extending the literal sense by illuminating the commented detail by parallel scriptural passages from both the Old and New Testament. Paralleling the motives sheds obviously a new light on canonical contextual understanding of the commented element and reveals its deeper theological and spiritual sense;

3 ) the next step of Aquinas' exegetical procedure is to show how the given motif was commented and interpreted by the Church Fathers. This aims at deepening the understanding the doctrina christiana revealed in living tradition of the Church.

4) the exegetical activity thus performed conducts where it is possible to reveal the mystical sense of the read and commented text, which in fact aims at allowing the reader to experience the bliss of eternity, that is entering by means of the sacred text into relation with the living God.

Now, I am going to discuss several exemplary motifs from John 21:1-6 demonstrating how Thomas applies in them his exegetical procedure and afterwards I will compare the results with the peak achievements of the present-day exegesis on the passage.

The first single motif explained by Thomas in John 21:1-6 is "after this" (Greek: meta tauta, Latin: postea). First, he exposes its literal sense: "after what the Evangelist has just narrated," 28 and then he continues:

«It is significant that he says this for it shows that Christ was not with them continuously, but appeared to them at intervals. The reason for this was that he had not risen with the same life as before, but with a glorious life, as the angels have and the blessed will have: "Except the gods", that is, the angels "whose dwelling is not with flesh" (Dan 2:11).»

This ends his exegesis of the expression "after this." Hence, according to the first step of his procedure, Thomas defines literal sense of the expression: "after this" which means "after what the Evangelist has just narrated." But right after this short and obvious information he goes directly to exposing, what we would call nowadays, "dogmatic" teaching, that is the sacra doctrina, which is not, in my opinion, literary present in John 21:1. Namely, Aquinas interprets the expression "after this" as indicating that Jesus was not constantly with his disciples, but appeared to them occasionally after his resurrection. Thomas 
does it to prove that Christ "had not risen with the same life as before, but with a glorious life." This is the kind of life that is already shared by angels and will be the final goal for the "blessed." Then, after this logical reasoning he gives the scriptural evidence from the Book of Daniel 2:11: "Except the gods whose dwelling is not with flesh." Some remarks have to be voiced here.

The first remark is philological. In the Vulgate of Daniel 2:11, Jerome's translation goes like this: "exceptis diis quorum non est cum hominibus conversatio" - lit. "Except Gods, with whom humans do not have conversation." If Thomas had used the Vulgate translation, the probative power of the sacred doctrine would have been much weaker, because it literary expresses a lack of communication between gods and humans, and not the issue of "the dwelling place of gods." But if we open the original Aramaic version of Da 2:11 and its translation in the Septuagint, things become much clear:

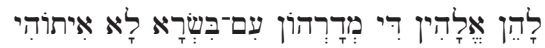

"Except gods, for whom there is not dwelling place with the flesh"

Old Greek (LXX) version of Dn 2:11b:

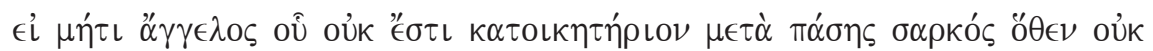

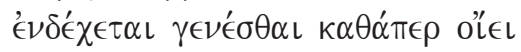

"If except angel for whom there is not dwelling place with all flesh. Whence what you expect cannot be fulfilled".

Theodotion's (shorter) version (II century AD):

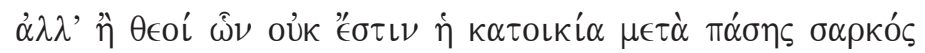

"Except gods for whom there is not dwelling place with all flesh"

It is evident that Thomas in his citation of Daniel 2:11 is closer to the Aramaic and/or Greek version that to Jerome's Vulgate. The Latin Vulgate translation "exceptis diis quorum non est cum hominibus conversatio" does not give sufficient data to develop the doctrinal teaching that Jesus "was not risen with the same life as before, but with a glorious life." It has to be noted here, that Aquinas' quotation of $\mathrm{Da} 2: 11$ is separated into two parts. After the first part "Except the gods," he clarifies "that is, the angels" and then continues "whose dwelling is not with flesh.” The clarification agrees partly with the Old Greek the Septuagint version where Aramaic אלָלדין which translates into Greek as $\theta \in o$ í and into Latin as diis is substituted by $\alpha \gamma \gamma \gamma \in \lambda$ o $\varsigma$ angel (sic! singular). Of course, 
in all probability, Aquinas did not know either Aramaic or Greek. Therefore his exegetical explanation inserted within the scriptural citation taken from the Vulgate (though scholars still debate what Latin translation Aquinas used) can be due to him referring to a patristic quotation of or allusion to $\mathrm{Da}$ 2:11 that followed the Old Greek translation (LXX) (preferably). One can conclude that in preparing lectures on John that became Reginald's reportatio and then were approved by the University of Paris as commentary on the Lectura super Joannem Aquinas was not a blind follower of Jerome's Vulgate, but carefully consulted patristic sources that in many instances were closer to original biblical texts than Jerome's Vulgate. Other way of explaining this issue is the need of doctrinal rational explanation - keeping the Vulgate version as it is Thomas would sound not clear enough in the realm of the doctrina christiana being close to a pagan notion that they are many gods, and thus the citation would not serve.

Aquinas' argument goes like that: The fact that Jesus appears to his disciples at intervals proves that he has not risen with the same flesh, but with the glorious one. Having returned in his glorious flesh to the glory of the Father, in his new condition, like angels and the "blessed", he is in another dwelling place, not in his earthly flesh. The quotation from $\mathrm{Da} 2: 11$ is to be interpreted as a scriptural proof of Jesus' heavenly glorification: he can no longer be with his disciples in the incarnated flesh, because for glorified heavenly beings "there is no dwelling place with all flesh." This doctrinal arguing must have been a needed response to a medieval dogmatic issue, since the Angelic Doctor explains it in the Summa Theologiae as well. ${ }^{29}$

As to the way Aquinas uses the citation from Daniel 2:11, it has to be stated that he does not pay attention to its original context which is a response of Chaldean's magicians, exorcists, and sorcerers to Nebuchadnezzar's demand to explain his dream. In responding they state: "For the question which the king asks is difficult, and there is no one else who shall answer it before the king, but the gods, whose dwelling is not with any flesh" (Da 2:11). As we know, the context of John 21 is entirely different. Thus, we can argue that Aquinas cites the part of verse $\mathrm{Da}$ 2:11 carefully cutting it from its original context in order to prove his doctrinal teaching. It should be seen as one of the features of his exegetical procedure.

The last issue that has to be dealt with concerning the aforementioned broad explanation of "after this - meta tauta" and its context in John 21:1 is a brief comparison of Aquinas' exegetical procedure and its results with the way

29 ST III, q 55, a. 3. It is notable that the third part of the ST was probably written by Aquinas while he lectured in Paris on the Gospel of John. 
present-day commentators on John would do it. ${ }^{30}$ First of all, we would explain it grammatically saying that it is an expression comprised of two words: the preposition meta and demonstrative pronoun (houtos, haute, touto) in accusative neutral plural form. From that we would conclude that the pronoun tauta being in plural refers to many instances, hence the phrase should be literary understood "after these things." Then, a contemporary Bible scholar would ask, as Thomas does, to what things/events it relates. The answer would go in the same direction as Aquinas', with the difference that the fact of not counting by the author of John 21the appearance of Jesus to Mary Magdalene would be explained (see above). The next step of the present-day investigation on meta tauta in John 21:1 would be a statistic inquiry on all the occurrences of the expression in the Fourth Gospel (and sometimes in other Gospels, the NT, the whole Bible) in order to assess its semantic competences. After examining all the instances of meta tauta in the Gospel of John the exegete can be more inclined to say to which events it relates and to judge what could be the time period between the appearances of Jesus recounted in John 20 and his final appearance to the disciples in John 21 . As one could rightly judge, this is very speculative and does not lead to any deep theological conclusion, whereas the advantage of Aquinas' exegetical model is that every commented detail is attributed with a theological significance.

Having shortly elucidated the expression "after this," Aquinas directly passes in his commentary to a very general issue, to which he dedicates approximately the same number of words as to explaining the phrase meta tauta.

"The Evangelist seemed to be ending his gospel before, when he wrote, these are written that you may believe. Why then, does he add on this appearance? Augustine gives a mystical reason for this, which is that this appearance signifies the glory of the future life, when Christ will appear to us as he is. And so the Evangelist puts this appearance after what seemed to be the end of his gospel so that this could be better understood." ${ }^{31}$

Interestingly enough, Thomas signalized the reason why the Evangelist added one more chapter after seemingly having ended the Gospel, right at the beginning of the lecture, ascribing the theological meaning to each of the three apparitions of the risen Christ (see above). But afterwards he left the issue in order to comment on the expression "after this." This is certainly not what

30 Status questionis of exegetical achievements on John 21 is given in: J. Kręcidło, Nowe życie uczniów Jezusa. J 21 jako owoc eklezjologicznej relektury J 1 - 20 we wspólnocie Umiłowanego Ucznia, Oficyna Wydawnicza 'Vocatio', Rozprawy i Studia Biblijne 33, Warszawa 2009.

31 Lectura super Joannem, nr. 2572. 
a present-day commentator on John would do! Legitimization of the presence of chapter 21 after apparently completed Gospel is one of the most debated matters in contemporary Johannine scholarship, because the way it is resolved is vital for the interpretation of theological meaning of both the whole chapter 21 (and consequently the entire FG as I will demonstrate further), and individual details present in it as well.

First, I am going to examine Thomas' explanation of that issue and then concisely demonstrate how modern-day exegetes deal with the problem. First and foremost, it has to be noted that Aquinas grasps the evident difficulty with integrating chapter 21 with the previous 20 chapters of the FG. Nonetheless, contrarily to what one would expect of him, a scholar to whom analytical reasoning and establishing literal sense of commented text was a primary step of exegesis, he crosses over the entire thinkable discussion, in order to appeal to authority of saint Augustine who "gives a mystical reason for this" in his Tractatus in evangelium Ioannis, the thing he had noticed already a while ago when collecting patristic citations on John 21:1-11 in his Catena aurea. ${ }^{32}$ Therefore the reason for the Evangelist to put the account on the risen Christ's appearance to what seemed to be the already ended Gospel was to reveal the doctrine on "the glory of the future life, when Christ will appear to us as he is." As I have already mentioned, revealing the mystical sense of commented text was the ultimate aim of Aquinas' exegetical activity. Thus, not wasting time for unnecessary discussion that can lead the reader astray from the utmost goal of reading Scripture, he goes straight to its mystical sense that gives the guarantee to capture the "eternal bliss" and be united with the Triune God, which is the final purpose of Christian life.

As I have stated above, the discussion concerning John 21 is very vivid in modern-day Johannine scholarship. Unlike Aquinas, contemporary scholars ask all historical and literary questions mentioned above, and only then try to explore theological significance of the final appearance of Christ to his disciples. I am going to relate briefly the focal points of the discussion. The first one concerns the status of John 21 in relation to chapters $1-20$ of the FG. Some researchers argue that it is an addition which relates to the already completed Gospel in a tenuous way, and consequently assigns to John 21 the status of an appendix. Having taken this assumption one is exempt from asking profound theological questions on the specific function of chapter 21 for understanding of the entire FG. Others, contrarily, think that the relation between the two entities is obvious, and that chapter 21 is an epilogue of the Gospel which in a smooth way completes its message. Yet, some of the contemporary Johannine

32 See: Tract. in Io. 122. 1; PL 35, col. 1959. 
scholars, including the author of the paper, assign to John 21 a special status of a paratext or a metatext added to the already completed Gospel on the last stage of its literary development in order to repragmatize its theological message in the light of an essential experience of the Risen Christ by the community of the Beloved Disciple. Therefore the final redactor/redactors added the chapter 21 to the already ended Gospel to give a new hermeneutical key that should be applied by audience when reading and interpreting the whole Gospel. The essential theological issue of John 21 concerns the manners of constant presence of the Risen Lord in the Church of all times. Thus, the originally Christological message of the FG was reinterpreted in an ecclesiological direction which is the new hermeneutical key given to readers. The author intends to awake and strengthen in the audience the awareness of constant and powerful presence of the Risen Christ in the Church, especially by means of its apostolic activity connected with obedience to his words which are present in Scripture (miraculous fishing), and the Eucharist (the meal prepared by Christ to his disciples).

To the best of my knowledge, no contemporary commentator of John 21 supports Aquinas' interpretation that the appearance of the Risen Christ to his disciples should be understood in the mystical sense explained above. To me his proposal was a very stimulating revelation. The two theological senses - ecclesiological and mystical - should not be put in opposition. The same scriptural passage can express more than one spiritual sense.

\section{Conclusion}

To sum up, one needs to answer the question: What is the prime advantage of the exegetical model applied by Aquinas for the present-day biblical exegesis and the spiritual life of the Church?

It must be emphasized here once more that the Angelic Doctor did not invent his own exegetical method. He was a faithful heir of the patristic tradition and pursued a career of a teacher (magister sacra pagina) deeply immersed in the medieval scholastic exegetical tradition.

The greatest advantage of Aquinas' exegetical method is that it is theologically oriented. It converges with the newest stream in the present day exegesis that is slowly but increasingly growing among Catholic exegetes, namely, that the only appropriate way of biblical interpretation is the hermeneutics of faith, as it was expressed by Pope Benedict XVI in his post-synodal Apostolic Exhortation Verbum Domini declared in September 2010, addressed to both Catholic scholars and believers. 


\section{Bibliography}

Baglow Ch.T., “»Modus et Forma«: A New Approach to the Exegesis of Saint Thomas Aquinas with an Application to the Lectura super Epistolam ad Ephesios.” Analecta Biblica 149, Rome 2002.

Childs B., The Struggle to Understand Isaiah as Christian Scripture, Grand Rapids 2004. Genette G., Palimpsestes: La literature au second degré, Editions Seuil 1982.

Healy N.M., "Introduction," in: Aquinas on Scripture: An Introduction to His Biblical Commentaries, ed. T.G. Weinandy, D.A. Keating, J.P. Yocum, New York 2005.

Kaiser W.C., Silva M., An Introduction to Biblical Hermeneutics: The Search for Meaning, Zondervan Publishing House, Grand Rapids 1994.

Klein W.W., Blomberg C.L., Hubbard R.L., Introduction to Biblical Interpretation, Nashville 1993.

Kręcidło J., "Hermeneutyka biblijna," in: Wstęp ogólny do Biblii, P. Walewski (ed.), Series Religiologica Pomeraniae 2, Rumia 2011.

Kręcidło J., Nowe życie uczniów Jezusa. J 21 jako owoc eklezjologicznej relektury J 1-20 we wspólnocie Umiłowanego Ucznia, Oficyna Wydawnicza 'Vocatio', Rozprawy i Studia Biblijne 33, Warszawa 2009.

Kristeva J., Semiotikè: recherches pour une sémanalyse, Paris 1969.

Prügl T., "Thomas Aquinas as Interpreter of Scripture," in: The Theology of Thomas Aquinas, ed. R. Van Nieuwenhove, J. Wawrykow, University of Notre Dame Press 2005.

Spivey J.T., Jr., “The Hermeneutics of the Medieval and Reformation Era," in: Biblical Hermeneutics: A Comprehensive Introduction to Interpreting Scripture, B. Corley, S.W. Lemke, G.I. Lovejoy (eds.), Nashville 2002.

Thiselton A.C., Hermeneutics: An Introduction, Grand Rapids 2009.

Thomas Aquinas, Commentary on the Gospel of John, vol. 1, Chapters 1-5, transl. F. Larcher, J.A. Weisheipl, Washington, D.C., 2010.

Thomas Aquinas, Commentary on the Gospel of John, vol. 3, Chapters 13-21, transl. F. Larcher, J.A. Weisheipl, Washington, D.C., 2010.

Tomas Aquinas, Summa Theologiae (Summa Theologica), New English Translation by A.J. Freddoso, J. and J. Oesterle: https://www3.nd.edu/ afreddos/summa-translation/TOC.htm (updated May 14, 2016).

Torrell J.-P., Saint Thomas Aquinas, vol. 1, The Person and His Work, trans. R. Royal, Washington, D.C., 1996.

Weinandy Th. G., Keating D.A., Yocum J.A., Aquinas on Scripture: An Introduction to his biblical Commentaries, T \& T Clark International, London, 2004. 